autloo lays stress on the hat effect of this condition on the general constitution, while the peculiar effect on the character and temperament of the child is also noted. The close comnection between ocular changess and pathological changes in the nose is well shown, but a great lack of illustrations is here felt, as well as in the whole section on pathology.

The subject of diagnosis has been very cleverly treaterl. The essential features necessary for a thorough knowledger of this difficult subject have heen well set forth. Transillumination as an aid to diagnosis in sinus troubles has, however, heen dismissed in rather a short fashion.

In dealing with the various pathologioal conditions met with in the nose and post-nasal space the author shows a widespreat knowledge of his subject, and his opinions are supported by numerous references.

Treatment has very heen thoroughly dealt with, and where operative interference is necessary the various operations are explained, so that the reater is given a number to choose from, and is thus able to suit the requirements of the individual cases.

Consilerable space is devoted to the treatment of sinus affections, lwth chronic and atente. The chapters are very well arranged amd malit most interesting reading. In the diagnosis of maxillary and frontal sinus suppuration, however, there is no use mate of transillumination and Röntgen rays as aids to diagnosis. Turner, of Edinburgh, has clearly shown what valuahle airls these are, and also in the case of the frontal sinus their great value in deciling as to operative interference.

Zarniko las presented to us a book most cleverly and corefully writtenl. The teaching of the Berlin school has been closely followed. 'This new mition makes a valuable contribution to our literature on the subject of natsal conditions.

J. II.

\title{
NEW APPLIANCE.
}

\section{"Vaporole" Chioride of Ammonium Inhaler.}

Burroughs Welleome \& Co., Lomion.

For compartness this is probably the most remarkable chloride of ammonium inhaler extant. It is contained in a cardboard box measuring
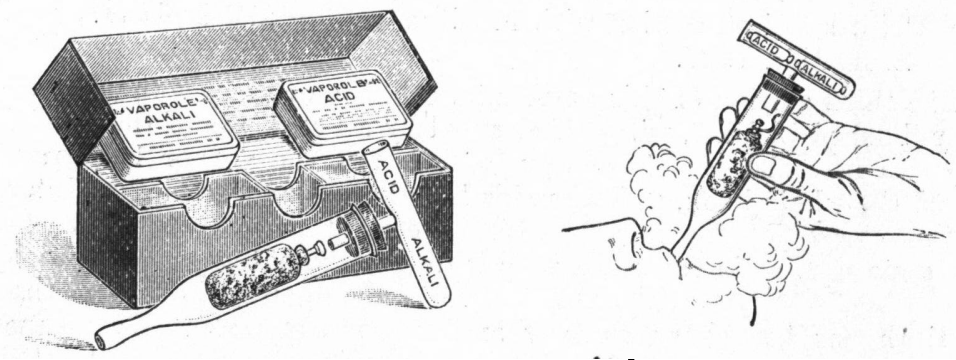

six inches in length by two and a quarter and two in other dimensions. This is rendered possible by the use of glisss "vaporole" tubes of two lifferent colours, containing hydrochloric acid and ammonia respectively. The method of use is simple, cleanly, and safe, and when the vaporoles supplied with apparatus are used up a fresh stock can be procured. The valpour is quite unirritating. 


\section{INDEX 'T'() VOLUNE XXV, 1910.}

\section{SUBJECTS.}

AbDuctor paralysis, vide Vocal cords.

Accidental Injuries to Workmen (H. N. Barnett) (review) . . 54

Acommetric formula (J. Möller) . . . . . . . 385

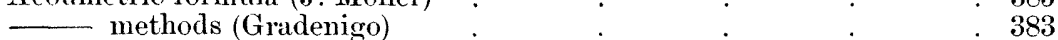

Adenoids, nasal, offshoots of (A. Meyer) $\quad . \quad * \quad . \quad . \quad . \quad . \quad 667$

- simulated by syphilis (Trapenard) . . . . 102

Adrenalin-cocaine anxsthesia, death after ('T. J. Harris) . . 271

Aërophagia (Castex and Parrel) . . . . 431

Air-passagres, changes in, in pregnancy, etc. (Imhofer) . . 580 direct examination of (discussion) . .605

Anerican Laryngological Association

$96,150,261,316$ Laryngological, Rhinological and Otological Society . 486,551,581

Anæsthesia, local, in ear surgery (J. J. Harley) . . . . 44.

Angeioma of auricle (G. Wilkinson) $\quad . \quad$. $\quad . \quad 146$

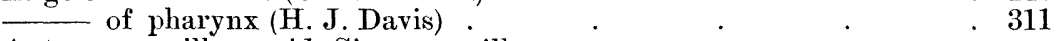

$\begin{array}{ll}\text { Antrum, maxillary, vide Sinus, maxillary. } & \\ \text { Aphonia,? diagnosis (C. Horsford) } & .\end{array}$

Asthma, nasal (Dan McKenzie) . $\quad$. $\quad$. $\quad$. $\quad$. 202 nasal cauterisation in (A. Francis) . $\quad . \quad . \quad . \quad 534$

Audition, vide Hearing.
Auditory and facial nerves, affections of (Is. Braun) .

\begin{tabular}{llr} 
Auditory and facial nerves, affections of (Is. Braun) . & $\cdot$ &. \\
\hline
\end{tabular}

Auricle, angeioma of, pulsating (G. Wilkinson) $\quad . \quad 1 . \quad . \quad 146$

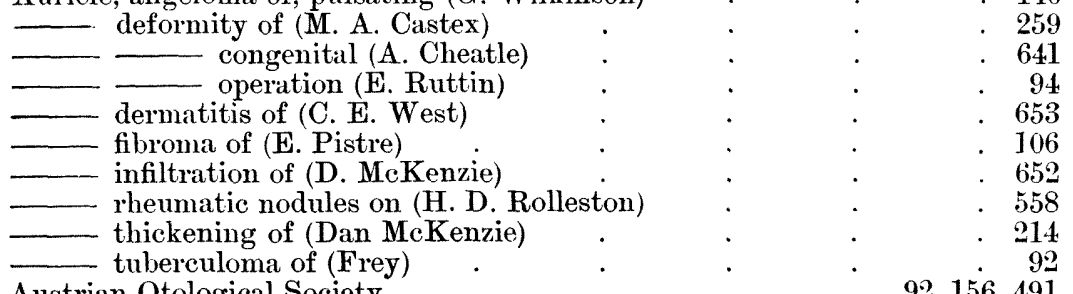

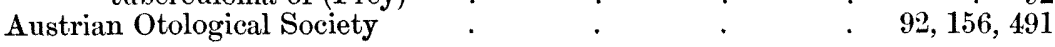

Baber, the late E. Cresswell, obituary notice $\quad . \quad$. 237

Bier's hyperæmia in aural suppuration (Biehl, Isemer, Spira) . 107, 321, 414

-1 in laryngeal tuberculosis (W. Howarth) $\quad . \quad 108$

Brain, abscess of (Compaired, Mr. C. Smith) $\quad$ • $\quad$. $\quad 328,671$

. 110

. 443

- vide also Cerebrum, and Cerebellum, abscess of.

British Medical Association Meeting

- 449

478,529

457,523

Bronchoscopy (Brünings)

Laryngological Section

. 479

discussion on

- 479 
Bronchoscopy, fatal (Chiari) in thoracotony (O. Gaub and C. Jackson) •

Bronchus, foreign bodies in, removal (H. Tilley, C. W. Richardson) 251,586

Calcium lactate in hæmorrhage (W. R. Simpson) 9 98, 166

Cancer, delayed recurrence of (H. Tilley) . . . . . 28

- protracted duration of $(\mathrm{H}$. Smith) . $\quad . \quad$. $\quad .263$

Cerebellum, abscess of, simulated (H. Tod). ․ . . . . 375 abscess of (S. Scott, W. H. Kelson). $\quad$. $\quad$. $\quad 649,654$

- tumours of, diagnosis (E. Jones) $\quad . \quad \cdot \quad \cdot 110$

Cerebrum, abscess of, following pan-sinusitis (Guisez) $\quad: \quad 432$

- latent, diagnosis of (G. Ferreri) $\quad . \quad 5 \quad 325$

otitic (M. Nicolas) $\quad: \quad: \quad .443$

frontal lobe of, rhinogenic abscess of (Guisez) . 432

temporal lobe of, alsscess of (F. Alt, G. T. Ross) $\quad 93,392$

without vomiting (A. L. Whitehead) . . 370

Cervical abscess, deep, from rori-sinu-iti-(S. Citelli) . 108

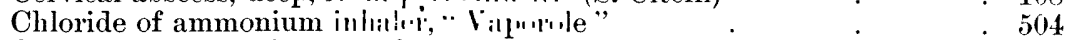

Cholesteatoma, pathogeny of (W. Wingrave) $\quad . \quad 539$

Chorea, naso-pharyngeal, origin of (S. L. de Ponthière) : $\quad$. 461

Cirsoid aneurysm of auricle (G. Wilkinson). $\quad . \quad$. . 146

Cocaine-adrenalin anæsthesia, death after (T. J. Harris) $\quad{ }^{*} \quad \cdot 271$

Common colds, ætiology of (A. Coolidge, jun.) . $\quad . \quad 555$

Cricoid cartilage, tuberculous perichondritis of (H. Barwell) $\quad . \quad 195$

Deaf-mutism, acquired, from congenital syphilis (M. Yearsley, O. Mayer)

- $\begin{gathered}\text { ptiology of (Urbantschitsch) } \\ \text { pathology of (A. A. Gray, A. Denker, E. Ruttin }\end{gathered}$

Deafness, chronic progressive, classification of (J. Möller) $\quad 46,225,329,658$

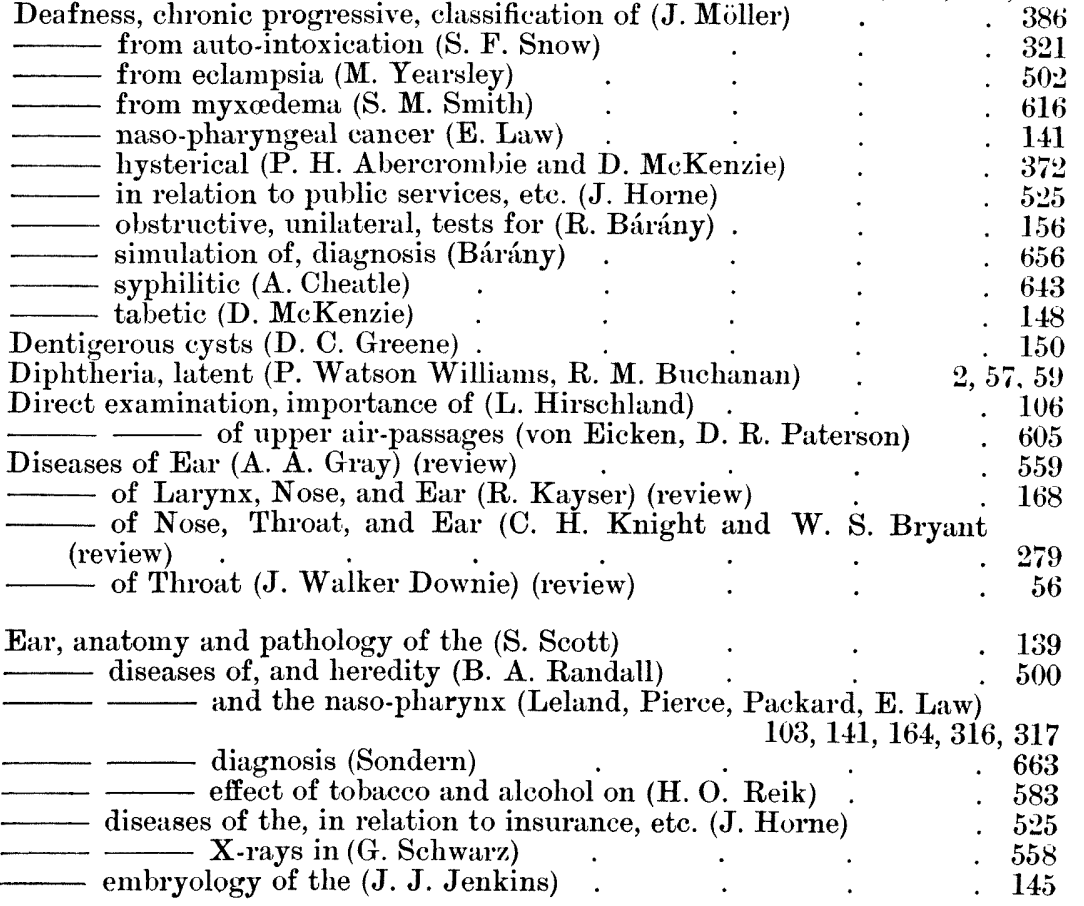




\section{Index.}

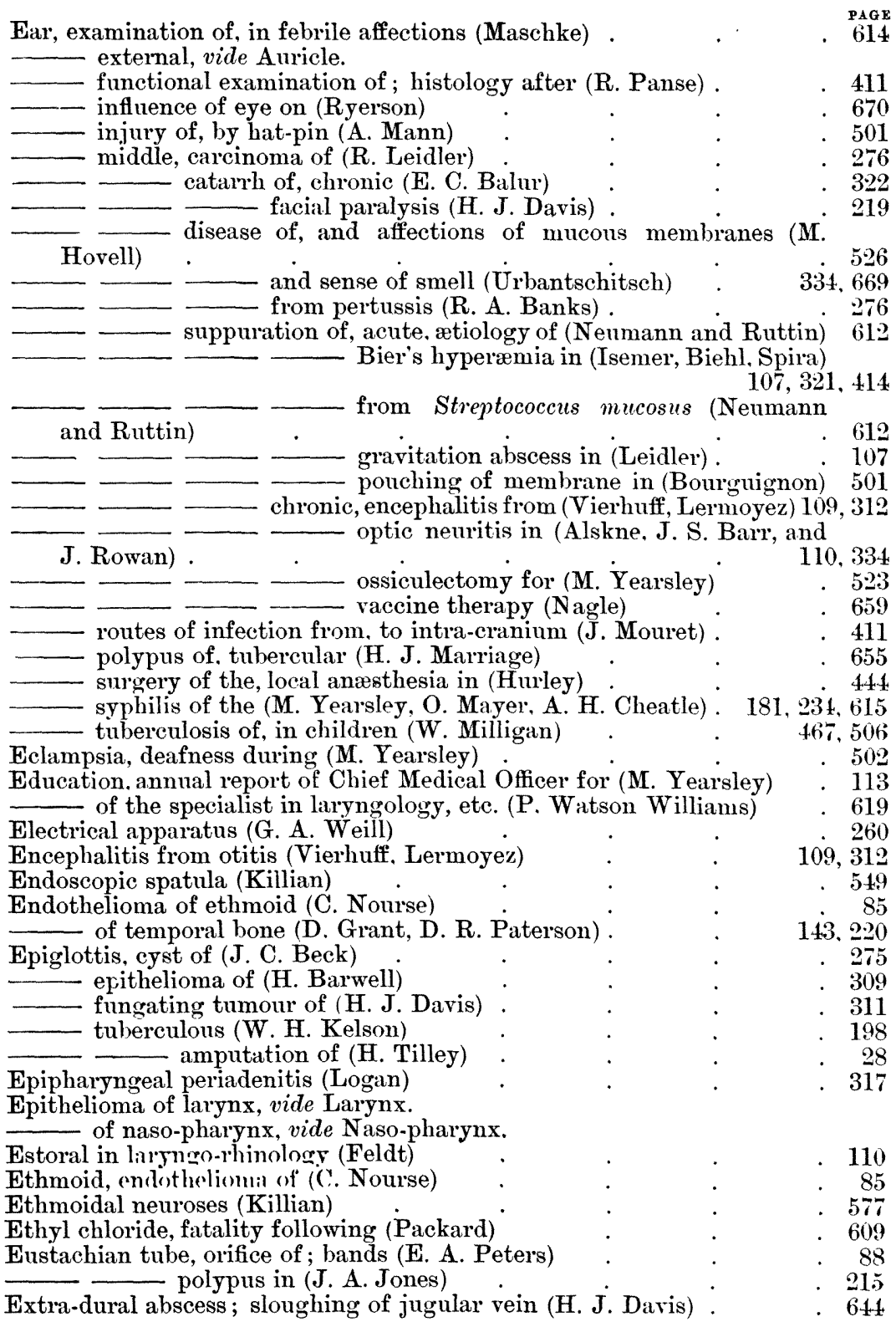

Facial and auditory nerves, affections of (Braun) . $\quad . \quad 94$

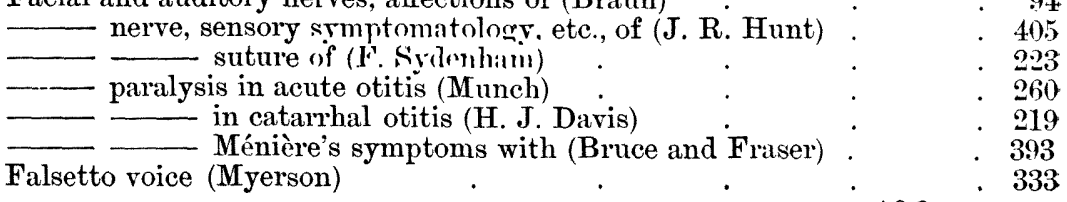


Fibrolysin contra-indications of (Stocker).

Fibroma of auricle (Pistre)

Foreign body in bronchus (H. Tilley) . . . . . $\quad 251$

in lung (H. J. Davis) 125

in esophagus (H. J. Davis, H. Tilley, Guisez. Jackson.

Frontal bone, osteitis of (Lermoyez) $\quad . \quad$. $\quad . \quad 312$ osteomyelitis of (C. J. Symonds) $\quad . \quad \quad . \quad 33$

Galvano-cautery in laryngeal tuberculosis (D. Grant, H. Tilley. J. Donelan)

Goitre, exophthalmic (J. G. Mumford)

134. 248,363 specimen of (J. Donelan).

Graves' disease, vide Goitre. exophthalmic.

Gravitation (subcephalic) otitic abscess (Leidler) . $\quad$. 107

Hæmophilia (T. Hubbard) $\quad . \quad$. $\quad$. $\quad$. $\quad 98$

Hæmorrhage, calcium lactate in (Simpson) $\quad \cdot \quad \cdot \quad \cdot \quad 98,166$

- from upper air-passages (Chiari) $\quad . \quad 101$

nasal; post-operative; prevention (Casselberry) $\quad . \quad 260$

Hay-fever, immunisation treatment of (Scheppegrell) $\quad . \quad$. $\quad 272$

Har'a nhervnenanne (W. Milligan) . . . . 47

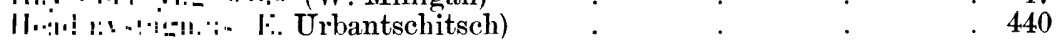

II.:14.

Hearing, tests for (Bárány) $\quad$. $\quad . \quad . \quad .656$

Heredity and ear-disease (Randall) $\quad . \quad \cdots \quad . \quad . \quad 500$

Hiatus semilunaris, removal of lip of, for catarh (D. Grant) . $\quad$. $\quad 255$

Hoarseness, case of (G. C. Catheart) $\quad . \quad$. $\quad 24.83$

Hyoid bone, fracture of (H. J. Davis) $\quad . \quad 1 \quad$. $\quad . \quad 127$

Ictus laryngis (H. J. Davis) . . . . . . 127

Implantation cysts of mastoid (Schoetz) $\quad \cdot \quad \cdot \quad \cdot \quad \cdot 106$

Instruments for throat, etc., new joint for (Kuttner) . $\quad . \quad$. $\quad .577$

International Congress of Medicine, Section of Laryngology . $\quad . \quad 599$

- — - of Otology . $319,383,411,495$

- Laryngo-Rhinological Congress . $\quad . \quad 101$

Interstitial keratitis, treatment of (S. Stephenson) $\quad . \quad$. $\quad . \quad 440$

Intra-cranial complications, rhinogenic (Freudenthal) $\quad$ • . 437

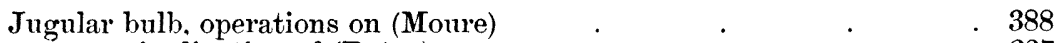

\begin{tabular}{llll}
- & $\cdot$ & $\cdot$ & \\
\hline
\end{tabular}

"Kloram" inhaler, the . . . 224

Krankheiten der Nase, etc. Die (C. Zarniko) (review) $\quad \cdot \quad \cdot \quad 503$

Kuhn's per-oral intubation (W. Milligan) ..$\quad$. $\quad . \quad 210$

Labyrinth, affections of, in lenkæmia (Krepuska) . $\quad$ • 322 \begin{tabular}{rrr} 
Labyrinth, affections of \\
\hline fistula of (Bárány. I. Sewell, G. Alexander) & $\cdot$ & $95,96.166 .670$ \\
\hline
\end{tabular} operative technique of surgery of (Bourguet). $\quad . \cdot 402$ symptoms, the significance of (G. E. Shambaugh, G. Alexander)

tests (G. W. Mackenzie) galvanic (G. W. Mackenzie) . $\quad . \quad$. $\quad 335$ in forensic medicine (Lermoyez and Hautant) . $\quad . \quad 427$

- post-operative (R. Lake and W. Pike) $\quad . \quad 40$

Labyrinthitis, acute (G. Alexander) $\quad 50$

infective (Hantant. Alexander, R. Bárány, C. West 3i3, 451, 4i3, 474 chronic (C. E. West) . . . 653 indication for operation (Schmiegelow, Bárány) $\quad 413,495.496$ 
Labyrinthitis, infective, pathology of (H. Neumann) .

vertigo (H. J. Davis)

Laryngectomy (H. Smith)

Laryngitis, chronic (H. B. Robinson)

Laryngology, History of (A. Jurasz) (review)

Laryngostomy (Guisez, Sargnon, and Barlatier)

G. S. Hett. P. Watson Williams, Fitzgerald Powell, E. A. Peters.

C. Nourse, D. Grant, W. Hill) 28, 30. 33, 81, 84, 91, 306, 308, 310, 362, 368

-_ diagnosis and treatment (Sir F. Semon, Chiari, Gluck) 599, 600

— for thirteen years (H. Smith) . . . . 263

\begin{tabular}{llr}
- & $\cdot$ & 588 \\
\hline- hemi-laryngectomy for (Berens) & $\cdot$ & $\cdot$
\end{tabular}

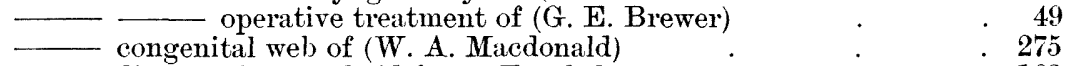

- disease of, in typhoid fever (Fränkel) : . $\quad .163$

- foreign body in (Monson). . . . . $\quad .557$

- functional disease of (L. H. Pegler). $\quad: \quad .368$

- hyperkeratosis of (Zwillinger) . . . . $\quad 604$

- in pregnancy, parturition, etc. (Imhofer) $\quad . \quad 5 \quad: 580$

- infiltration of, unilateral (D. Grant) . . . 310

- lipoma of (M. A. Goldstein) . 222

- n neoplasm of, cases of (P. R. W. de Santi, P. Watson Williams,

W. G. Porter)

œdema of, acute, after ether (Mason and Inglis)

$32,84,310,390$ chronic (Veillard) paralysis of, vide Vocal cords.

sarcoma of (Salzburg)

stenosis of (W. Hill, Guisez)

- cure (StClair Thomson) inspiratory, of (StClair Thomson)

Leçons sur les Suppurations de l'Oreille Moyenne, etc. (Dr. Luc) (review)

Leukoplakia of soft palate (A. Wylie)

Lingual thyroid (W. G. Spencer) .

Lip, syphilitic ulceration of (C. Nourse)

Lumbar puncture for aural vertigo (Weill, etc)

Lymphocytes, tonsillar, origin of (Wood) . 
Mastoid abscess from peri-sinusitis (Citelli) . $\quad 108$ cells, histology of (J. J. Jenkins) $\quad 143$ epidermic, cysts of (Schoetz) . $\quad . \quad 106$

\begin{tabular}{lll}
\hline infantile (A. H. Cheatle) & $\cdot$ & $169,205,328$
\end{tabular}

- $\ldots$ operation, adventitious membrane after (H. J. Davis) .

Maxilla, superior, osteomyelitis of (Samenhof)

Maxillary antrum. vide Sinus, maxillary. sinus, vide Sinus, maxillary.

Meatus, external auditory, adventitious membrane in (H. J. Davis) $\quad 218$

- affections of (Sheppard) . $\quad . \quad . \quad 59$

- - atresia of, congenital (Ruttin. Váli, A. Cheatle) $\quad 94,417$

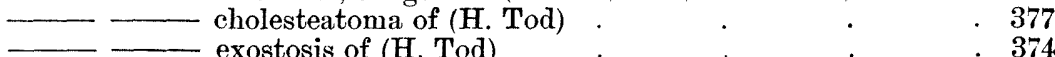

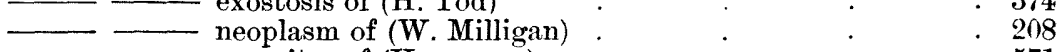

- parasites of (Hemmeon) . . . . . . $\quad .571$

Membrana tympani, artificial (Bárány) $\quad . \quad 0 . \quad$. $\quad . \quad 491$

- papilloma of (H. J. Davis) . $\quad . \quad$. $\quad . \quad 219$

$\longrightarrow$ pouching of, in acute otitis (Bourguignon) $\quad . \quad+501$

traumatic perforation of (Zebrowski) .
Ménière's syndrome (D. McKenzie)

treatment of (B. Thornton)

with facial paralysis (A. Bruce and J. S. Fraser)

Meningitis, acute otitic, treatment (Dench) .

after labyrinthitis (H. Luc)

\begin{tabular}{lll}
\hline- & 614 \\
\hline
\end{tabular}

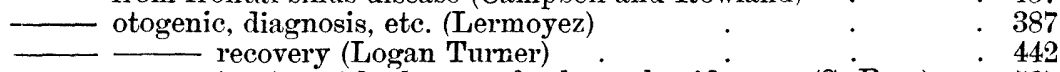

- treatment by lavage of sub-arachnoid space (S. Barr) . 527

Menthol dermatitis of nose (D. McKenzie). . . . 301

Model of larynx, etc. (R. S. Spicer) $\quad . \quad$. $\quad . \quad 25$

Mouth, congenital deformity of (A. R. Tweedie) $\quad . \quad 191$

Mucosus otitis (Neumann and Ruttin) $\quad \cdot \quad \cdot \quad \cdot 612$

Mucous membranes, affections of, relative to ear, etc. (M. Hovell) $\quad$. 526

Myxœdema, deafness from (S. M. Smith) . $\quad . \quad . \quad .616$ \begin{tabular}{l} 
Naris, anterior, occlusion of (N. Patterson) \\
\hline posterior, occlusion of, congenital (D. McKenzie, D. R. Patter-
\end{tabular}

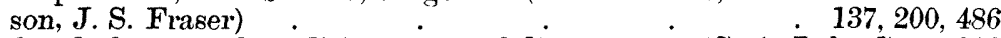

Nasal and pharyngeal conditions in aural diseases, etc. (G. A. Leland) . 316 speech, surgical treatment of (Fröschels) . . . $\quad 158$

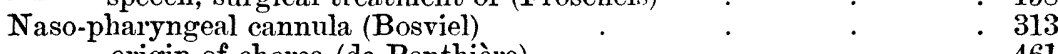

Naso-pharynx and disease of ear (G. A. Léland, E. Law, N. H. Pierce,

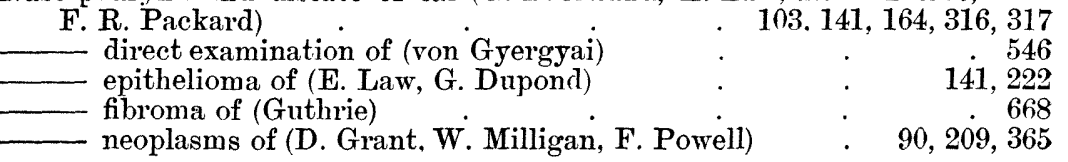




\section{Index.}

Naso-pharynx, scleroma of (StC. Tho:nson) .

syphilis of (Trapenard)

Nose, accessory sinuses of, vide Sinuses, nasal.

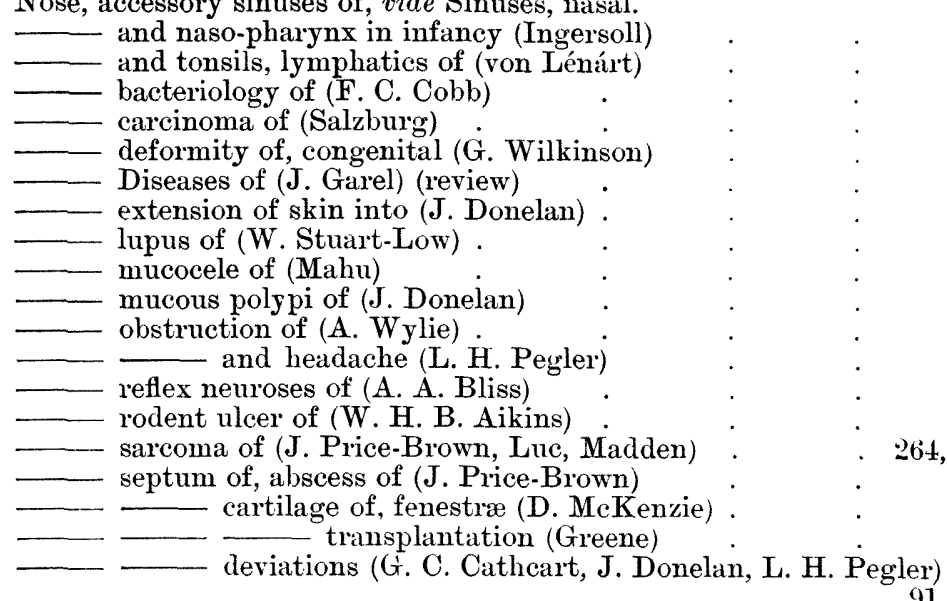

633

102

269

102

268

547

131

167

138

133

315

255

$366^{\circ}$

- $5+4$

. 97

555

$264,314,436$

- 272

. 632

. 330

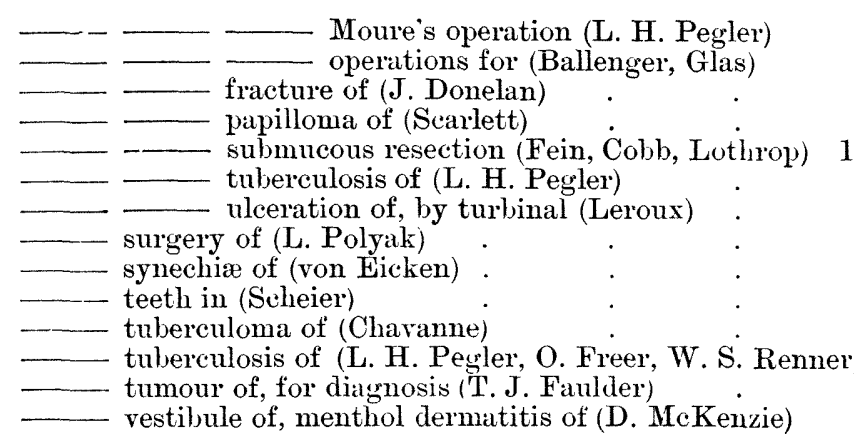

$91,252,254$

. 252

270,611

. 136

$666^{\circ}$

$16: 2,433,486,611$

253

. 428

. 418

. 422

. 610

. 105

$253,266,267$

. 638

. 301

Ocular effects of sphenoidal sinus tumours (Halasz) . . . . 162

Odynphagia in a tuberculous subject (D. Grant)

Esophage, Traité des Maladies de l' (Guisez) (review) $\quad . \quad 671$

Esophagus, carcinoma of (Pepler, W. Hill)

$3 \div 3,368$

635

$33,203,634$ - radium in (W. Hill) .

. 479 foreign bodies in (H. J. Davis, H. Tilley, Guisez, Strazza)

removal of (C. Jackson)

$127,303,432,607$

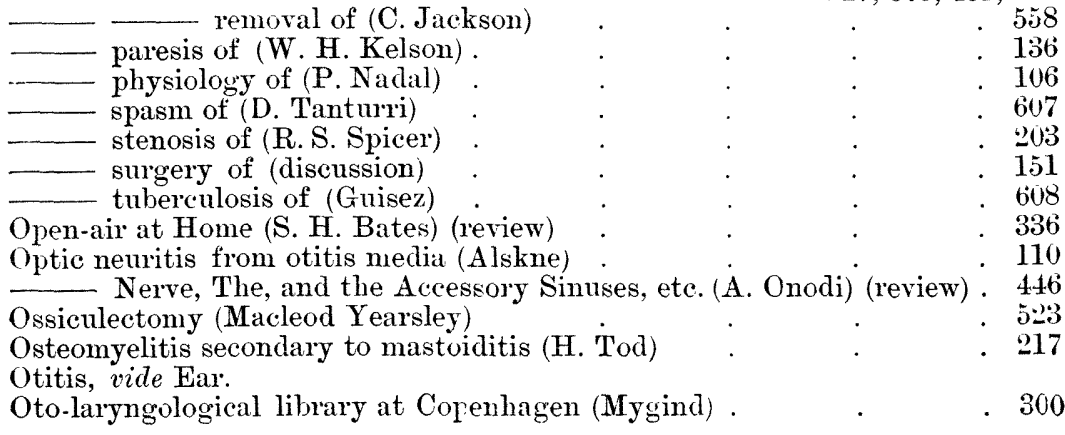


Otology, retrospect of

Otosclerosis (T. Heiman)

Ozæna and breathing exercises (R. Foy)

Palate, congenital insufficiency of (A. B. Kelly, Laurence)

-

— paresis of (W. H. Kelson)

redness of (D. Grant)

- teratoma of (Coffin)

- ulceration of ( $\mathrm{F}$. Powell and Badgerow) spasms of (Castex and Parrel)

- tumours of (Badgerow)

- ulceration of ; syphilitic (Lawrence)

- with sequestrum (D. Grant)

Palato-pharyngeal adhesions (J. O. Roe)

Palmer's speculum. modified (P. Lamrens) .

Pansinusitis (StC. Thomson, Guisez)

Parisian Society of Iarrnenglugry. Otology, etc.

Pemphigus of throat (li. .11. Murd)

Pergetans of larynx, etc. (H. J. Davis)

Per-oral intubation, Kuhn's method (W. Milligan)

Peri-sinusal alsscess (Citelli)

Peri-tonsillar alsscess, treatment of (Flatau)

Pharyngitis, syphilitic, with nerve symptoms (D. Grant)

Pharyngoscope, Hay's (W. Milligan)

Pharynx and Lary nx for 1909

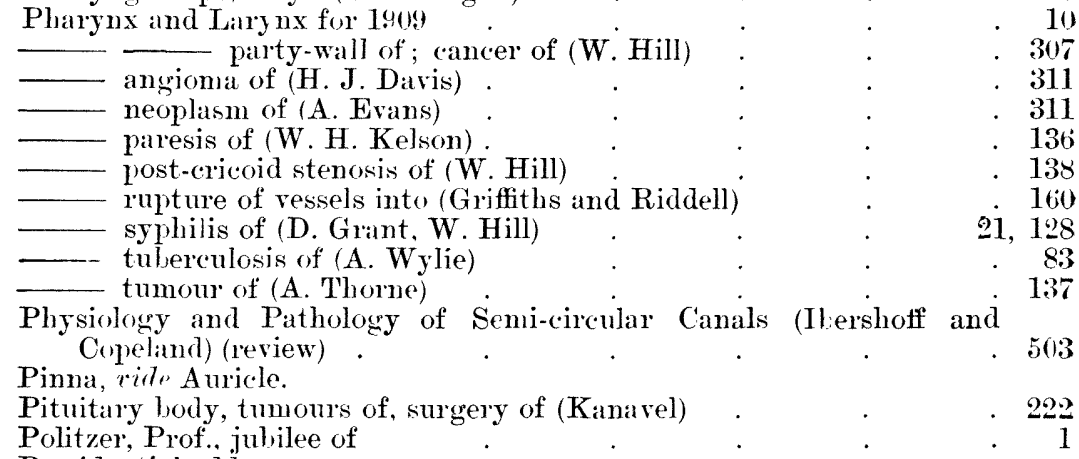

Presidential addresses:

British Medical Association, Laryngological Section (H. Tilley) . 478 Otological Section (E. Law) $\quad . \quad 467$

Royal Society of Medicine, Laryngological Section (P. Watson Williams) 


\section{Index.}

Radium in malignant disease of neck (W. Hill)

- in osophageal cancer (W. Hill)

Report of the Ear and Throat Department, etc. (W. G. Porter and G. M. Darling)

Retro-cerebellar abscess (S. Scott)

Retro-pharyngeal abscess and mastoiditis (Fallas)

Rhinitis, atrophic, early forms of (Baumgarten) tuberculosis after (Cabouche)

Rhinology ; a Text-book of Diseases of the Nose (P. Watson Williams) (review) retrospect of

Rhinophyma (Hoffmann)

Royal Society of Medicine, Laryngological Section

Scarlet fever, fatal hæmorrhage in (Griffiths and Riddell)

School-children, throat examination of (Cones)

Scleroma of naso-pharynx (StC. 'Thomson) .

Scottish Otological, etc., Assuciation

Singers' node (E. A. Peters)

Singing, observations on pupils of (Nadoleczny)

Sinus, cavernous, thrombosis of (L. A. Coffin, H. J. Davis)

Sinus, frontal, exostosis and mucocele of (Manasse) .

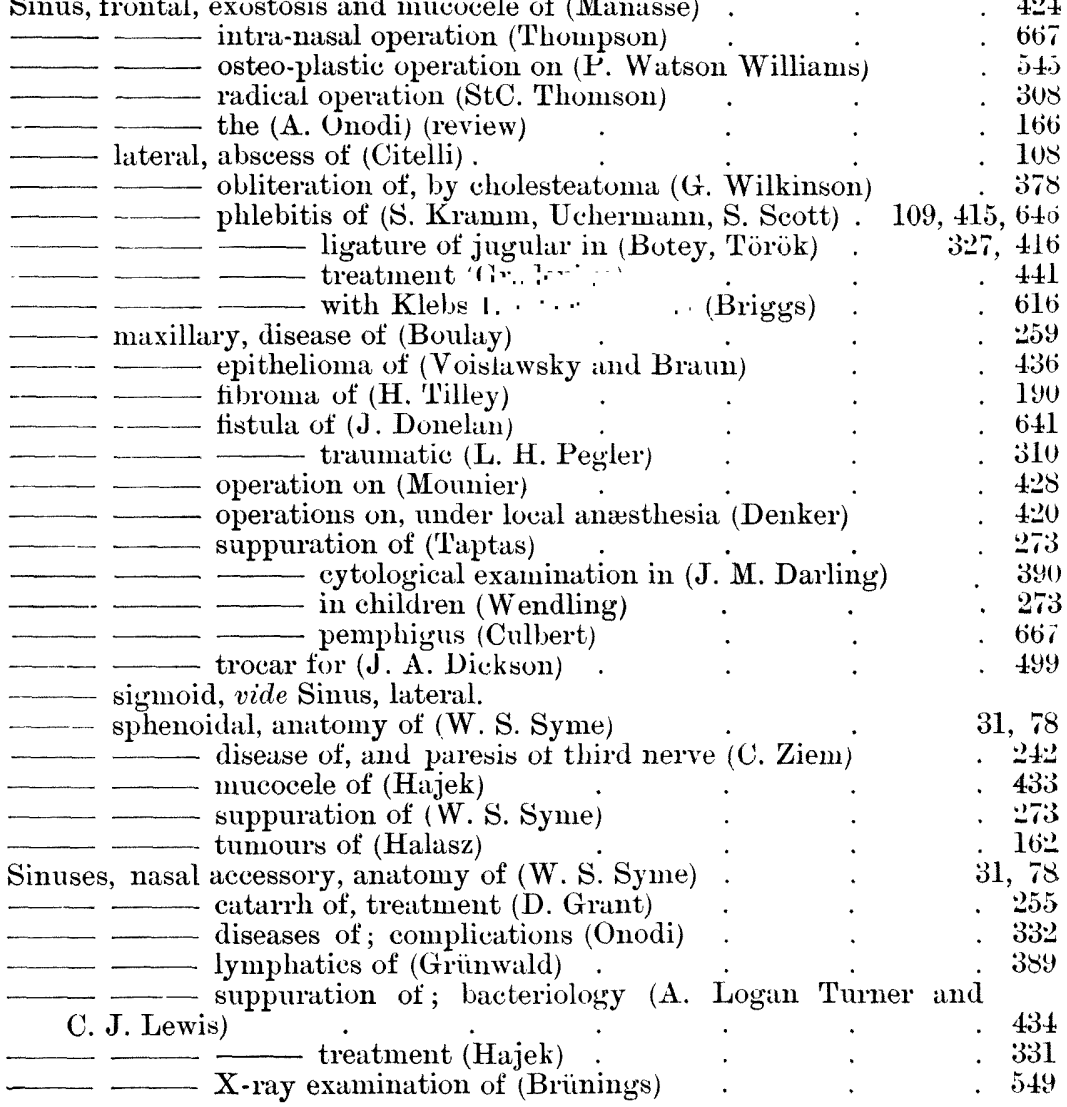


PAGE

Sinusitis, frontal, meningitis from (Campbell and Rowland) . . 437

—- treatment of (Citelli) $\quad \cdot \quad \cdot \quad \cdot \quad \cdot \quad \cdot 330$

— with fistula (H. Tilley) . . . . . . 191

- with necrosis (W. H. Kelson) . . . $\quad 22$

Smell, influence of ear-disease on (Urbantschitsch)

Sneezing (de Champeaux) . . . . . 272

Society of German Laryngologists, Transactions $\quad$. $\quad 418,546,576,656$

Sound, perception (D. B. Kyle) . . . . . 278

Sphenoid, sarcoma of (F. Voss) . $\quad . \quad$. $\quad . \quad$. $\quad . \quad .436$

Spheno-palatine fossa, fil,roma of ; operation (Hansberg) . . . 422

Stammering and nasal disease (R. S. Spicer) . . . . 204

Status lymphaticus, death from (T. J. Harris) ～. ～. . . 271

Styloid process, prolonged (C. W. Richardson) $\quad . \quad 5 . \quad 100$

Supra-tonsillar region, tumour of (W. Hill) . . . . . 256

Syphilis, Die, der Nase, etc. (P. H. Gerber) (review) . . . 448

- in relation to otology (discussion) . $\quad . \quad$. $\quad .572$ treatment of (Cushing)

Syphilitic nerve-deafness (A. Cheatle) $\quad . \quad 5 \quad$. $\quad . \quad 643$

Tabes, deafness from (D. McKenzie) . $\quad$. $\quad$. $\quad .148$

Teeth in nasal cavity (Scheier) . . . . . . 610

Temporal bone, endothelioma of (D. Grant, D. R. Paterson) : $\quad 143,220$ fracture of (G. J. Jenkins, A. Cheatle) . . 382, 642

- infantile type of (A. Cheatle) $\quad . \quad 169,205,328$

_- malignant growth of (P. Watson Williams) . $\quad . \quad 169$

- sarcoma of (Bowen and Carlyll) . . . . . 502

Temporo-sphenoidal lobe. vide Cerebrum.

Third nerve, paresis of (C. Ziem)

Throat, cancers of the, etc. (R. S. Spicer) Diseases of the (J. Walker Downie) (review) . syphilis ending in cancer of (Massei)

Thyroid cartilage, perichondritis of (H. Barwell) gland, vide Goitre.

Tinnitus aurum, audible (H. Tilley, A. Sharp)

Tissue antiseptics, etc. (Cushing).

Tobacco and alcohol, effect of, on ear, etc. (Reik)

Tongue, cancer of (R. C. Myles)

- excision of entire (H. J. Davis)

- tuberculous ulcer of (H. J. Davis)

Tonsil, anatomy of capsule of, etc. (G. S. Hett)

development of (H. A. Barnes)

- embryology of (E. B. Wood)

- embryology of (E. B. Wood)

242
545

.
.$\quad 55$
.$\quad 56$

604,610

. 196

$39,147,214,335$

. 110

. 583

. 100

. 305

. 130

540,561

. 262

. 261

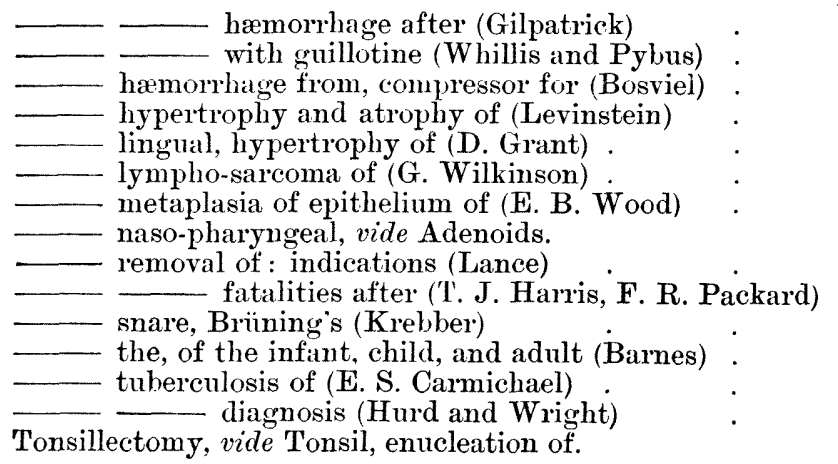

$103,153,438,541$

. 609

. 609

313

. 102

. $36^{2}$

. 133

. 261

556

271,609

. 256

- 262

. 390

Tonsillectomy, vide Tonsil, enucleation of. 


\section{Index.}

Tonsillitis, acute, nephritis following (H. W. Loeb)

Tonsillolith (C. A. Parker)

Tonsils and adenoids, operations on (Ingersol) lymphatics of (v. Lénárt) physiology and pathology of (Schoenemann) submerged, forceps for (H. Tilley)

Trachea, cancer of, primary (Berens)

direct examination of (discussion)

diverticulum of (Kahler)

foreign body in (D. J. G. Wishart) .

papilloma of $(\mathrm{H}$. Tilley)

swelling of lining of (Utfenorde)

syphilis of (Haenel)

tuberculosis of (T. Guthrie)

ग51

638

609

102

48

Tracheotomy, subglottic swelling after (H. Barwell) . . . . $\quad 633$

Tubereulin in Diagnosis and Treatment (Bandelier and Röpke) (review) 11:

Tuberculosis of larynx, vide Larynx. of Nose and Throat (L. B. Lockard (review) .

Turbinal hypertrophy (J. Domelan)

inferior, vascular tumour of (E. Berinard, S. Hastings) middle, bone cysts of (Skillern)

$104,19 \cdot$

Turbinotomy, submucous (Zarniko)

Tympanic plates, congenital defect of (C. E. West) .

Typhoid fever, laryngeal disease in (Frankel)

- 551

- 425

. 200

Uvula, adhesion of, to tonsil (J. Horne)

163

- carcinoma of (E. M. Holmes)

Vaccine treatment of aural suppuration (Nagle)

Vaso-motor neuroses, nasal cauterisation in (A. Francis) rhinitis (discussion)

Vertigo, aural; lumbar puncture (Weill) galvanic, and aural troubles (Babinski) laryngeal (H. J. Davis)

Vincent's angina (J. D. Rolleston)

Vocal cords, abductor paralysis of (H.J. Davis, Castex, D. McKenzie)

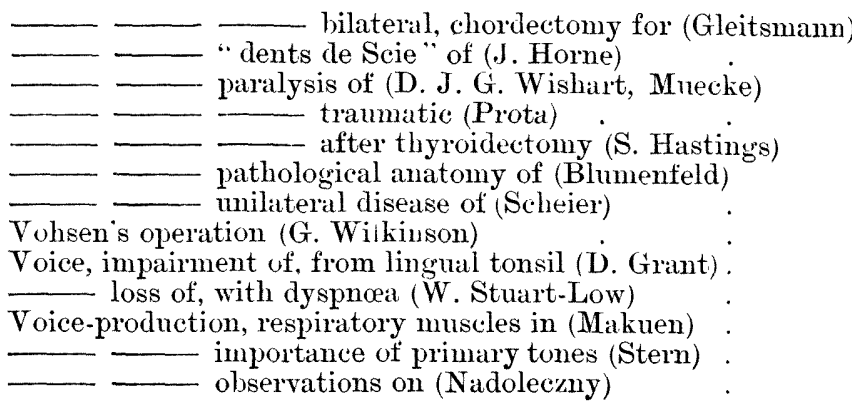

$\mathrm{X}$ rays in otology (Birkett, Schwarz)

Zaufal, Prof., death of . 


\section{AUTHORS.}

Abercrombie (P. H.) and McKenzie (Dan), hysterical deafness

ADAMs, mnemonic tables, etc.

Aikins (W. H. B.), rodent ulcer

AleXANDER (G.), acute labyrinthitis purulent labyrinthitis nystagmus

ALSKNE, otitis and blindness

ALr (F.), cerebral abscess

Arrowsmith (H.), Vincent's angina

BABER (E. Cresswell), otitis media

Babinsk I (M. J.), galvanic vertigo, etc.

Badgerow (C. A.), palatal tumour

Ballenger (W. L.), septal operations

BANKs (R. A.), pertussis

BÁRínY (R.), artificial drum

cerebellar ataxia, etc.

- hearing tests

_ labyrinth fistula labyrinthitis

Bardswell (Noel), case for diagnosis

Barlatier, Sargnon and, laryngostomy

Barnes (H. A.), development of tonsil

BARR (J. Stoddart), treatment of meninges and Rowan (J.), optic neuritis, etc. .

BARRÉ, aural vertigo

BARWELL (H), cancer of larynx epithelioma of epiglottis perichondritis subglottic stenosis

tuberculous perichondritis.

BaUMGarten (E.), ozæna

BECK (J. C.), cyst of epiglottis

Berens (T. P.), cancer of trachea . hemi-laryngectomy

BERGH (E.), palatal cyst

BIEнL, Bier's hyperæmia

BIRKETT, mastoid radiography vaso-motor rhinitis

BLISs (A. A.), nerve disturbances, etc.

BLUMENFELD (F.), vocal cords

Bosviel, retro-nasal cannula tonsil compressor

Botey (R.), ligature of jugular

Boulay (M.), maxillary antrum

Bourguet, labyrinth operations

BouRGUIGNON (R.), pouching of membrane

Bowen (W. H.), and CARLYLL (H. B.), sarcoma of petrous

BrAUN (Is.), auditory nerve affection

BREWER (G. E.), laryngeal cancer

Brigas (G. N.), sinus thrombosis .

BROECKHAR'T (J.), recurrent paralysis

Bruce (Alex.), and Fraser (J. S.), Ménière's symptoms, etc. .

BRüNINGS (W.), new appliances. radiography

Buchanan (R. M.), latent diphtheria 
CABOCHE, atrophic rhinitis

CaMPBELL and Rowland, frontal sinus meningitis

Carmichael (E. Scott), tuberculous tonsils

Casselberry (W. E.), nasal hæmorrhage.

CASTEX, deformity of auricles paralysis of abductors and PARré, aërophatgia

Castinel, aural vertigo

CathCaR'T (G. C.), hoarseness occlusion of nostril tuberenlosis of larynx

Chavanne (F.), tuberculosis of nose

Cheatre (A. H.), aural syphilis fracture of temporal bone. infantile mastoid malformation of auricle

Chiari (O.), hamombage, ete. laryngeal cancer . fatal bronchoseopy

Citelir (S.), deep cervical alsscess frontal sinusitis laryngeal stenosis

Совв (F. C.), bucteriology of nose. submucous resection

Cofres (L. A.), cavernous sinus thrombosis palatal teratoma .

COMPAIRED. brain abscess

Cones (W. P.), school examination

Coolidae (A., jun.), common colds - Presidential address

Culbert (W. L.), pemphigus

Cushing (A. R.), tissue antiseptics

DARLING (J. M.), maxillary antrum Porter (W. G.) and (report, etc.)

Davis (H. J.). abductor paralysis . adventitious memlane. etc. angioma of pharynx avernous sinus thromliosis excision of tongue extra-dural abscess facial paralysis foreign hody in lung fracture of ophagus

laryngeal case

laryngeal vertigo .

papilloma of membrane pemphigus

tuberculosis of tongue

De Champeaux, sneering

De Colo (F.), palatal tumours

De Ponthiere (S. L.), chorea. ete.

De Santi (P. R. W.), liryngeal neoplasm

DENCH (E. B.), otitic meningitis

Deniser (Alfred), deaf-nutism maxillary antrum

Drckson (T. A.), antrum trocar

Doneran (J.), extension of skin, ete. maxillary antrum fistula. nasal polypus 
Donelan (J.), septal deflection .

septal fracture
specimen of goitre
tuberculosis of epiglottis

DUPOND (G.), naso-pharyngeal cancer

Evans (A.), pharyngeal neoplasm .

Fallas (A.), mastoiditis, etc.

FAUlder (T. Jefferson), case for diagnosis

FEIN (J.), window resection

Feldt (A.). estoral

FERRERI (Gherardo), cerebral abscess

Flatad, peritonsillar abscess

Fournié (J.), mastoiditis

Foy (R.), ozæna

Francis (Alex.), asthma, etc.

FRINKEL, upper air-passages in typhoid

Fraser (J. S.), choanal occlusion .

Br UCE (A.) and, Ménièrès symptoms, etc.

Freer (Otto), nasal tuberculosis .

Freudenthal (W.), endocranial complications, ete. laryngitis dolorosa

Frey (H.), tuberculoma of ear

Fröschels (E.), nasal speech

GAUB (O.) and JACKsON (C.), bronchoscopy

GIBB (J.S.), extirpation of tonsil .

GILPATRICK (H. H.), tonsil hæmorrhage

GLaS (Emil), septal deviation

GleitsMian, chordectomy

GLUCK, cancer of larynx

Goudstein (M. A.), lipoma of larynx

Gradenigo, acoumetric methods. lateral sinus thrombosis

Grant (J. Dundas), alcohol injections for odynphagia

- endotheliona of temporal bone

- laryngeal infiltration

— laryngeal tuberculosis

- lingual tonsil

- malformation of soft palate

- naso-pharyngeal grow ths .

odynphagia

_ _ redness of soft palate

- _ removal of lip of hiatus, etc.

___ secondary syphilis with nerve symptoms

specific pharyngitis

ulceration of palate, etc.

GraY (Albert A.), deaf-mutism

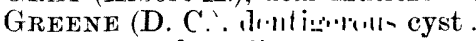

$\longrightarrow$ septal ratribil on"

Griffiths (J. H.) and Ridpdel (D. F.), rupture of vessels, etc.

GRÜNWALD, sinus lymphatics

GuISEz, foreign bodies, etc.

laryngostomy

cesophageal tuberculosis

- pansinusitis

Guthrie (J.), tracheal tulerculosis

Guthrie (T.), naso-pharyngeal fibroma 
HАJEK (M.), sinus suppuration . . . . . . 331

- . $\quad . \quad . \quad . \quad .433$

HAlasz (H.), sphenoidal sinus tumours $\quad \cdot \quad .163$

HANSBERG, spheno-palatine fibroma . . . 42.

HARris (T. J.), cocaine-adrenalin ; death . . 271

Hastings (Somerville), bleeding polypus . $\quad . \quad . \quad 192$

HaUtant, labyrinthitis .

and LERMOYEZ, vestibular nystagmus $\quad . \quad 427$

Hegener, stereoscopic laryngoscope

Herman ('Theodor), otosclerosis

Hemmeon, parasite of meatus

Hetr (G. Seccombe), capsule of tonsil laryngeal cancer .

HrLL (W.). epithelioma of larynx . - epithelioma of cosophagus . œsophageal intubation apparatus papilloma of larynx party-wall cancer post-cricoid stenosis radium in cancer of neck. - in osophageal cancer tonsillar tumour. traumatic laryngeal stenosis tuberculoma of larynx

Hrrschland (L.), direct examination

HoFfMANN (R.), rhinophyma

Holmes (E. M.), cancer of uvula

Horne (Jobson), adherent uvula. deafness and work "Dents de Scie"

ventricle of larynx

Horsford (Cyril), aphonia

Hovelu (Mark), affections of mucous membianes, ete.

How ARTH (W.), laryngeal tuberculosis

HuBbaRd (T.), hæmophilia

Hunt (J. Ramsay), facial nerve .

HuRD (L. M.). pemphigus and WRIGHT (J.), tonsil tuberculosis

HuRley (J. J.), local anæsthesia .

IGLAUER (S.), mastoid operation .

IMHOFER, air-passages in pregnancy, etc.

INGERSOL, tonsil operations

Ingersolu (J. M.), infantile nose, ete.

IsEmer (F.), Bier's hyperæmia

JACKson (Chevalier), safety-pin in gullet

- GaUB (Ottr) and. hprnmonomp

J

JENKINS (G. J.), embryology of ear - histology of mastoid fracture of temporal bone .

Jones (E.), cerebellar tumour Jones (J. Arnold), Eustachian polypus

KAHLER (O.), tracheal diverticulum KANABEL (A. B.), pituitary tumours KELLY (A. Brown), insufficiency of palate Kelson (W. H.), cerebellar abscess frontal sinusitis paresis of palate, etc. tuberculosis of epiglottis . 
Killian, endoscopic spatula ethmoidal neuroses

KraMm (S.), sinus phlebitis

KREBbER, Brünings' tonsil snare

KREPUSKa (Geza), labyrinth in leukæmia

Kuttner (A.), new joint, etc.

KYLE (D. Braden), sound-perception

Lake (R.). and Pike (N.), labyrinth tests

LANCE (M.), removal of tonsils)

LAwrens (Paul), speculum

LAW (E.), naso-pharyngeal epithelioma

Presidental addresses

LAWRENCE (L.). absence of palate

syphilitic ulceration

Le Marc'hadour, palatal abscess

LEIDLER (R.), cancer of ear

- gravitation abscess

LELAND (G. A.), naso-pharyngeal conditions, ete.

Lermoyez. frontal osteitis otogenic meningitis serons encephalitis and HAUTANT, vestibular nystagmus

LERoux (Robert), nasal polypus .

LEUTERT, blood examination

Levinstein (O.), histology of tonsils, ete.

LEVY (Oskar), brain abscess

Loeb $(H$. W.). acute nephritis

Logan (Jas. E.), epipharyngeal peri-adenitis

LOTHROP (O. A.), submucous resection tonsillectomy

LUC (H.), jugular phlebitis nasal sarcoma

Macdonald (W. A.). laryngeal web

McKenzie (Dan), abductor paralysis enucleation of tonsil

- - infiltration of auricles

- laryngeal infiltration Ménière’s syndrome menthol dermatitis

- nasal asthma

- occluded choana.

- septal cartilage fenestra

- tabetic deafness :
thickening of auricles

Abercrombie (P. H.) and, hysterical deafness

MACKenzie (Geo. W.), galvanic labyrinth tests lalyrinth tests

MADDEN, sarcoma of nose

MAHU, infiltration of larynx

nasal mucocele

Mainwaring-White (R. M.), sinusitis

MaKUen (G. Hudson), voice-production

Manasse, exostoses of frontal sinus

ManN (A.), injury of ear

MARRIAGE (H. J.), tubercular ear polyp

MASCHKE, routine otoscopy

MASON (H. R.) and INGLIS (H. J.), cedema of larynx, ete.

Masser, syphilis and cancer

MAYER (Otto), syphilitic deafness 
McNaughton-Jones, aid to hearing

Meyer (A.), tonsils

Milligan (W.), aural tuberculosis

Hay's pharyngoscope

Kuhn's per-oral intubation

meatal neoplasm .

- naso-pharyngeal growth .

MöLLER, ozæna

MöLLER (Jörgen), acoumetric formula chronic deafness .

Monson, foreign body in larynx.

Mosher (H. C.), brain abscess

MounIER, maxillary sinusitis

Moure, operations on jugular bulb

Mouret (J.), intra-cranial infection, etc.

MUECKE, laryngeal paralysis

MuMford (J. G.), Graves' disease

MUNCH, facial paralysis .

Myerson (A.), falsetto voice

MYGIND (Holger), oto-laryngological library

Myles (R. C.), cancer of tongue .

NadoleczNy, singing

NAGLE (E. W.), vaccine therapy

NeUBAUER, radical mastoid

NeUmanN (H.), lahyrinthitis and Rutrin (E.), acute otitis

Nicolas (M.), otitic pyæmia

Nourse (Chichele), endothelioma of ethmoid epithelioma of larynx

frontal sinusitis

ulceration of lip .

OnoDI, sinus disease

Packard (F. R.), fatality after operation naso-pharynx and ear

Panse (R.), histology. etc., of ears

Parker (C A.). tonsillolith

PARREL (R.), adenectomy and CASTEX, aërophagia

Paterson (D. R.), choanal ocelusion direct examination, etc. endothelioma of temporal bone

Patterson (N.), occlusion of anterior naris

Pegler (L. H.), functional laryngeal disease nasal headache, etc. perforation of bony palate septal fissure septal tuberculosis

Pepier (W. H.), cesophageal cancer

Prerce (N. H.), naso-pharynx and ear, etc.

Pierre-Nadal (L.), physiology of esophagus

Pike (N.), Lake (R.) and, labyrinth tests.

Pistre (E.), fibroma of auricle

Polyak (T.), intra-nasal surgery .

Porter (W. G.). liryngeal tumours and D.IRrivi: (J. M.) (report, ete)

Powell (Fitzgerald), laryngeal case naso-pharygeal neoplasm . post-nasal tumour 
Powelu (Fitzgerald) and BADGerow, ulcer of soft palate . $\quad{ }_{637}^{\text {PAGE }}$

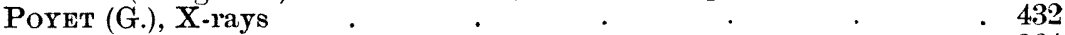

Price-Brown (J.), nasal sarcoma. $\quad . \quad$. $\quad . \quad 264$

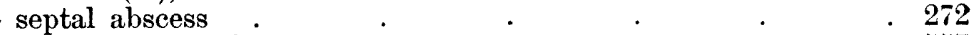

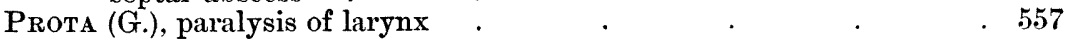

RANDALL (B. A.), heredity and ear disease . . . . 500

REIK (H. O.), effect of tobacco, etc. ․ . . . . . . . $\quad . \quad 583$

RENNER (W. Scott), nasal tuberculosis $\quad . \quad 1 \quad$. $\quad . \quad . \quad 267$

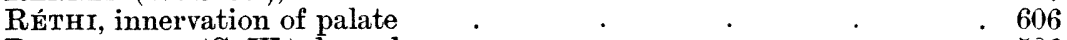

Richardson (C. W.), bronchoscopy $\quad$. $\quad$. $\quad$. $\quad .586$

- prolonged styloid process . $\quad . \quad . \quad . \quad 100$

RidderL (D. F.), GRiffiths (J. H.) and, rupture of ressels, etc. $\quad . \quad 160$

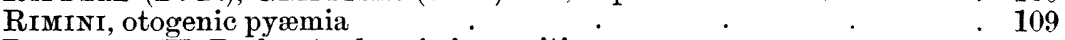

Robinson (H. Betham), chronic laryngitis . . . . . . . . . . .

ulcer of arytænoid

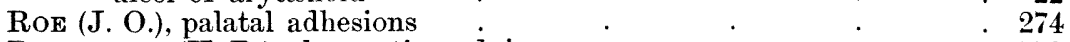

Rolleston (H. D.), rhenmatic nodules - . $\quad$. $\quad . \quad$. $\quad . \quad 558$

Rolleston (J. D.), Vincent's angina $\quad$. $\quad$. $\quad$. $\quad .499$

Ross (Geo. T.), temporo-sphenoidal abscess $\quad$. $\quad$. $\quad$. 392

Rothschimd (J.), congenital laryngeal stridor $\quad . \quad$. $\quad$. 48

Roughton (E. W.), cancer of larynx ‥ . . . $\quad 33$

Rowan (J.), BARR (J. S.) and, optic neuritis, ete. . . . . $\quad 334$

Rutrin (E.), meatal atresia $\quad . \quad \ldots \quad$. $\quad . \quad . \quad 94$ deaf-mutism . . . . . . . 658 NeumanN (H.) and, acute otitis $\quad . \quad+\quad . \quad \cdot 612$

RYERson (G. S.), eye and ear . $\quad . \quad \cdot \quad \cdot \quad \cdot \quad \cdot \quad \cdot 670$

Salzburg, sarcoma of larynx, etc. $\quad . \quad$. $\quad . \quad$. $\quad . \quad 547$

SAMENHOF (L.), maxillary osteomyelitis . . . . . . $\quad 47$

SARGNON and Barlatier, laryngostomy . $\quad . \quad$. $\quad .606$

$\begin{array}{llllll}\text { Scarlett (R.), septal papilloma . } & \text {. } & . & . & . & 666\end{array}$

Scherer (Max), unilateral laryngeal disease $\quad . \quad$. . . $\quad 275$

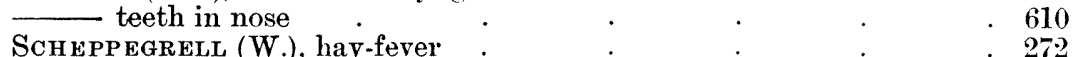

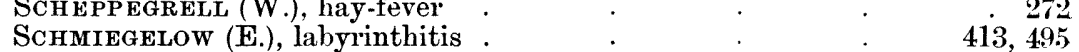

Schoeneman, physiology, etc., of tonsils . $\quad . \quad 4 \quad . \quad 48$

Schoetz (W.), mastoid epidermic cysts . . . . . . . $\quad . \quad 106$

Schwarz (G.), X rays in otology . $\quad . \quad$. $\quad . \quad . \quad 558$

Scotr (Jas.), vaccine treatment . $\quad . \quad . \quad . \quad . \quad 107$

Scotr (Sydney), lateral sinus thrombosis $\quad . \quad+\quad . \quad . \quad . \quad 646$

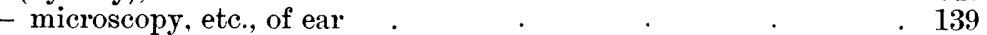

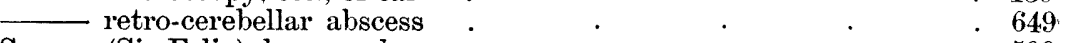

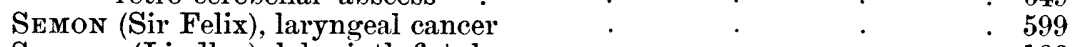

SEwell (Lindley), labyrinth fistula $\quad . \quad 166$

Shambaugh (G. E.), labyrinth symptoms . $\quad$. $\quad$. $\quad .391$

Sharp (Alexander), audible tinnitus . . . $\quad$. $\quad 214,335$.

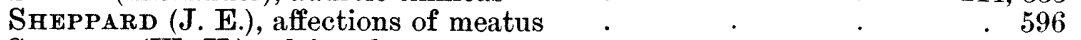

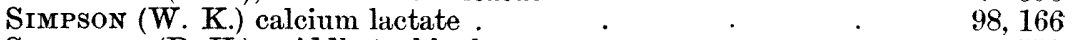

SkrLlerN (R. H.), middle turbinals $\quad . \quad 5 \quad$. $\quad$. 551

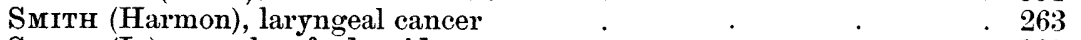

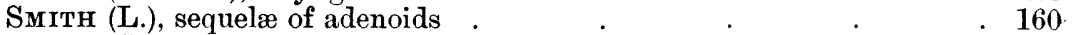

Sмгтн (S. MacCuen), myxœdema . $\quad . \quad 1.616$

\begin{tabular}{llll} 
brain abscess &. &. &. \\
\hline
\end{tabular}

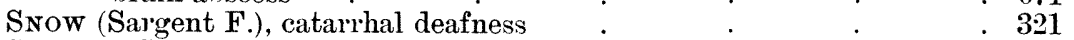

Somers (S. L.), cedema of palate . $\quad . \quad \ldots \quad . \quad . \quad . \quad 667$

Sondern (F. E.), otological diagnosis $\quad . \quad \ldots \quad . \quad . \quad . \quad 663$

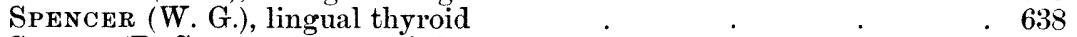

SPICER (R. Scanes), cancer of throat, etc. $. \quad \quad . \quad . \quad . \quad 545$

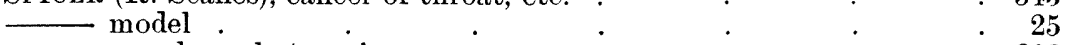

\begin{tabular}{llllll} 
& cesophageal stenosis & $\cdot$ & $\cdot$ & $\cdot$ & $\cdot$ \\
\hline
\end{tabular}

stammering . $\quad . \quad 2 \quad . \quad . \quad 204$.




\section{Index.}

SPIRA, Bier's hyperæmia

STARR (M. A.), auditory nerve-tumours Stephenson (Sydney), interstitial keratitis STERN (Hugo), voice-production .

Stocker (S.), fibrolysin .

Strazza (G.), foreign body in aesophagus

STUART-Low (W.), loss of voice lupus

SxdenhaM (Fred), suture of facial nerve

Syme (W. S.), spheno-ethmoidal cells, etc. . sphenoidal sinusitis

Symonds (Charters J.), frontal osteomyelitis

TanturRI (D.), cesophageal spasm

Taptas (N.). maxillary sinusitis.

ThOMPson (J. A.), frontal sinus

Tномson (StClair), frontal sinus operation

_ pansinusitis ${ }^{\circ}$

scleroma of $1, \ldots$

Thorne (Atwood), $\ldots \ldots \ldots$

Thor Non (Bertram), vaso-constrictor drugs

Trluey (H.), amputation of epiglottis)

candible tinnitus

- cancer of larynx .

filroma of antrum

foreign body in bronchus.

in gullet .

frontal sinus fistula

papilloma of larynx

Presilen trachea

Presidential Address

tonsil vulsellum .

tuberculous laryngitis

ToD (Hunter), cholesteatoma of meatus exostosis of meatus

osteomyelitis and mastoiditis simulated cerebellar abscess

Тӧкӧк, ligation of jugulitr

TRAPENARD, naso-pharyngeal syphilis

TURNer (A. Logan), otitic meningitis

- and LEWIS (C. J.), sinus suppuration

T'weEde (A. R.), congenital mouth deformity model of jaws

UCHERMANN (V.), otogenic pyæmia

UFFENORDE, curettage of trachea .

Urbantschitsch (Ernst), deaf-mutism

head nystagmus . position of head, etc.

URBANTSCHITSCH (Viktor), sense of smell, etc. olfactory perception, etc.

VÁLI (E.), congenital meatal atresia 
VON LÉNíRT (Z.), lymphatics of nose . . . . PAGE

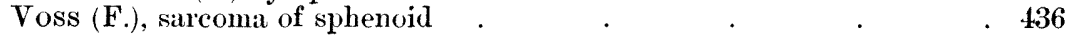

WAGGETT (E.), vaso-motor rhinitis _ . . . . . 531

WATERMAN (J. S.), laryngeal abscess $\quad . \quad+\quad . \quad 551$

WEILL (G. A.), ammal vertigo . . . . . 257 electrical apparatus

WENDLINA, maxillary antrum suppuration.

WEST (C. E.), congenital defect, ete. . . . . . dermatitis of pinnia

— labyrinth surgery $\quad . \quad . \quad . \quad . \quad . \quad . \quad 473$

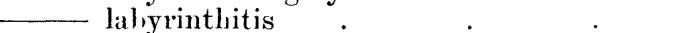

Whiluis (S. S.) and PybUs (F. C.), tonsil enucleation : : 609

Whitehead (A. L.), temporo-sphenoidal alscess . . . . 370

Wilkinson (Carmac), laryngeal tulerculosis : $\quad . \quad 538$

Wilkinson (Geo.), angeioma of auricle . . . . . . 146 deformity of nose

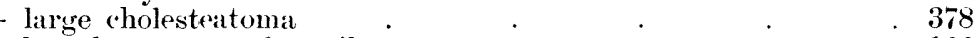

- lymphosarcoma of tonsil . . . . . . $\quad .133$

Williams (P. Watson), ? cancer of larynx . . . . . b41

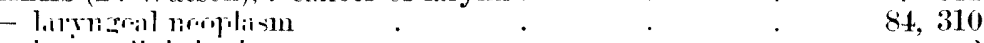

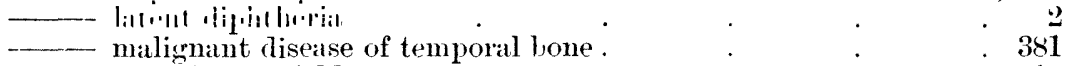

- Presidential Address . . . . . . 619

W surgery of frontal sinus . . . . . . . . 545

WINCKLER (E.), retro-auricular fistula . . . . . 501

submucous resection . $\quad . \quad 5 \quad . \quad 421$

WingRAVE (V. Wyatt), pathogeny of cholesteatoma _ . . 339

WISHART (D. J. G.), foreign body in trachea $\quad$. 439

W laryngeal paralysis $\quad . \quad 5 \quad$. $\quad .333$

Wood (G. B.), embryology of tonsils, etc. : $\quad: 261$

WyLIE (Andrew), leucoplakia .

- obstruction of nostrils . . . . . . . . . 366

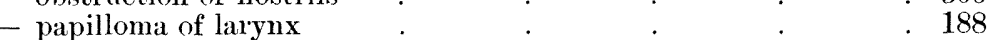

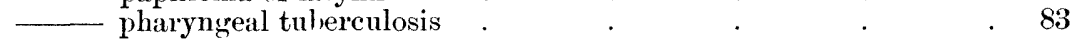

Yearsley (P. Macleod), annual report, ete. . . . 113

- deaf-mutism $\quad$. 181,934

deafness during eclampsia. $\quad . \quad \quad . \quad 502$

ossiculectomy . $\quad . \quad$. 50.523

ZARNiKo (Carl), submucous turbinotomy . . . . . 425

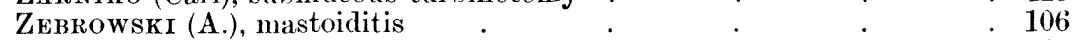

Zrem (C.), paresis of third nerve : $\quad . \quad$. $\quad . \quad$. 242

ZwILLINGER, laryngeal keratosis : $\quad . \quad+\quad . \quad$. $\quad .604$ 
